\title{
Maksilektomi Inferior pada Karsinoma Sel Skuamosa Palatum Durum
}

\author{
Sukri Rahman, Bestari Jaka Budiman, Irwan Triansyah, Heru Kurniawan Anwar
}

\begin{abstract}
Abstrak
Karsinoma Palatum Durum adalah keganasan daerah kepala dan leher yang jarang terjadi dimana setengah diantaranya merupakan Karsinoma Sel Skuamosa. Pada fase awal keganasan ini dapat bersifat asimptomatis namun dapat juga menimbulkan gejala berupa ulkus yang terasa nyeri pada perkembangan penyakitnya. Operasi maksilektomi inferior merupakan salah satu pilihan tindakan yang dapat dilakukan dalam tatalaksana kasus ini, diikuti oleh pemberian radioterapi. Kasus ini dibuat untuk memahami penatalaksanaan karsinoma palatum durum. Dilaporkan kasus seorang laki-laki 45 tahun dengan diagnosis Karsinoma Sel Skuamosa Palatum Durum (Well to Moderately Differentiated Keratinized) stadium IVa (T4aNOM0) dilakukan operasi maksilektomi inferior, namun tidak diikuti dengan radioterapi karena pasien menolak. Maksilektomi inferior merupakan pilihan pembedahan pada tumor yang terbatas pada palatum, lantai sinus maksila dan kavum nasi. Prognosis karsinoma sel skuamosa palatum durum cukup baik dan angka harapan hidup lima tahun akan bertambah bila dilakukan operasi diikuti dengan pemberian radioterapi.
\end{abstract}

Kata kunci: Karsinoma sel skuamosa, maksilektomi inferior, radioterapi

\begin{abstract}
Carcinoma of the hard palate is a rare head and neck cancer in which half of it was Squamous Cell Carcinoma. In the initial phase of this malignancy may be asymptomatic, but can also cause symptoms such as painful ulcers in the development of the disease. Inferior maxillectomy is one of the choice of operation that can be performed, followed by radiotherapy to understand the management of carcinoma of the hard palate. Reported one case of a man 45 years old with diagnosis Squamous Cell Carcinoma of hard palate (Well to Moderately Differentiated Keratinized) stage IVa (T4aNOMO) treated by inferior maxillectomy surgery, but not followed by radiotherapy because the patient refused. Inferior Maksilektomi is a surgical option in tumor that limited to the palate, floor of the maxillary sinus and the nasal cavity. Prognosis of the squamous cell carcinoma of the hard palate is good and the five-year survival rate will increase if surgery followed by radiotherapy.
\end{abstract}

Keywords: Squamous cell carcinoma, inferior maxillectomy, radiotherapy

Affiliasi penulis : Bagian IImu Kesehatan THT-KL RSUP dr. M. Dajmil Padang / Fakultas Kedokteran Universitas Andalas Padang Korespondensi : irwan.triansyah@gmail.com Telp: 0751-37194

\section{PENDAHULUAN}

Keganasan pada daerah kepala dan leher sering ditemukan di seluruh dunia dengan angka prognosis keganasan di rongga mulut lebih buruk dibandingkan lokasi lainnya. ${ }^{1}$ Karsinoma palatum durum merupakan satu diantara keganasan yang ditemukan pada rongga mulut. Angka kejadian karsinoma palatum durum hanya $5 \%$ dari seluruh keganasan rongga mulut dengan 53\% diantaranya merupakan karsinoma sel skuamosa. ${ }^{2,3,4}$

Etiologi karsinoma palatum durum berkaitan erat dengan gaya hidup merokok dan alkohol, diet rendah antioksidan dan virus HPV 16. Faktor resiko lain munculnya karsinoma palatum durum yaitu higienitas rongga mulut yang jelek, iritasi mekanik seperti kawat gigi palsu, syphilis dan kekurangan asupan vitamin. $5,6,7$
Gejala klinis karsinoma palatum durum umumnya asimptomatis. Keluhan yang tersering adalah nyeri dan rasa tidak enak di rongga mulut. Kadang didapati keluhan gigi goyah pada pasien. ${ }^{5}$

Terapi pilihan pada karsinoma palatum durum yaitu eksisi tumor. Tumor yang berukuran kecil dilakukan eksisi transoral. Maksilektomi inferior menjadi pilihan apabila tumor berada di palatum dan dasar sinus maksilaris dan rongga hidung (Gambar 1). Bila tumor memenuhi semua rongga palatum durum, tindakan yang dilakukan adalah maksilektomi total. $^{2,4,6}$ Tindakan operasi dapat dikombinasikan dengan radioterapi, tergantung dari karakteristik tumor. $^{2,3}$ 


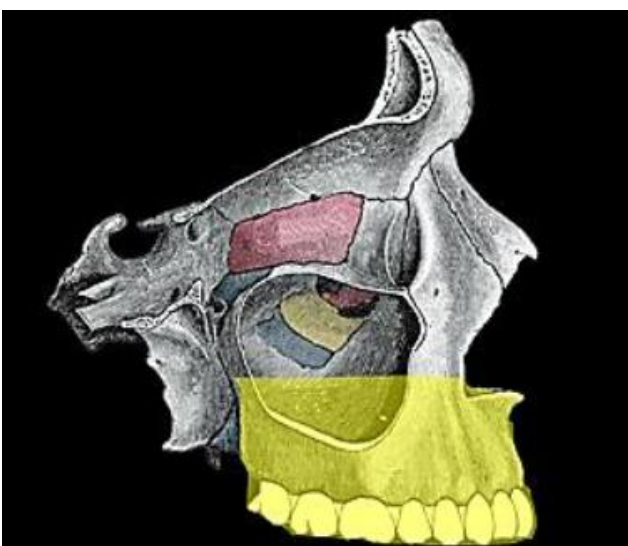

Gambar 1. Daerah yang direseksi pada maskilektomi inferior

\section{LAPORAN KASUS}

Seorang laki-laki berusia 45 tahun datang ke poliklinik THT-KL RSUP dr. M. Djamil padang pada tanggal 5 Oktober 2012 dengan keluhan utama bengkak di langit-langit mulut sejak 3 bulan sebelumnya, semakin lama dirasakan semakin membesar, bengkak terasa nyeri sejak 1 bulan terakhir. Sukar dan nyeri menelan tidak ada, hidung tersumbat tidak ada, bengkak di wajah tidak ada, benjolan di leher tidak ada. Gigi pada rahang kiri atas dirasakan goyang semenjak sakit.

Tidak ada riwayat keluarga yang menderita penyakit seperti ini. Pasien bekerja sebagai tukang kayu sejak 1 tahun yang lalu, riwayat merokok ada sejak \pm 25 tahun yang lalu, banyaknya sekitar 1 bungkus per hari, berhenti sejak 1 bulan terakhir, tidak ada riwayat mengkonsumsi alkohol.

Pada pemeriksaan umum pasien, kondisi pasien tampak sakit sedang, kesadaran composmentis, temperatur $36,7^{\circ} \mathrm{C}$, nadi $80 \mathrm{x} /$ menit, frekuensi nafas 20x/menit. Pada pemeriksaan telinga dan hidung dalam batas normal. Pada pemeriksaan rongga mulut tampak massa di palatum durum sisi kiri berwarna kemerahan (Gambar 2), ukuran $\pm 2,5 \times 1 \times$ $0,5 \mathrm{~cm}$, permukaan tdak rata, kenyal, terfiksir, dirasakan nyeri bila ditekan. Pada pemeriksaan tenggorok tampak arkus faring simetris, uvula ditengah, tonsil $T_{1}-T_{1}$ kripta tidak melebar, detritus tidak ada.

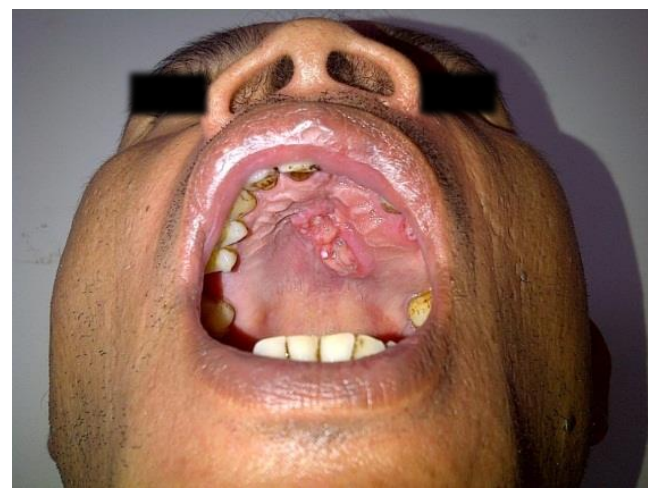

Gambar 2. Tampak massa pada palatum durum sisi kiri.
Berdasarkan anamnesis dan pemeriksaan fisik pasien didiagnosis dengan tumor palatum durum, dilakukan biopsi tumor palatum dalam anestesi lokal, jaringan yang diambil di periksakan ke laboratorium Patologi Anatomi (PA).

Karena alasan finansial pasien baru kontro ulang ke poliklinik THT-KL setelah 3 minggu dengan membawa hasil pemeriksaan histopatologi dengan kesan: Squamous Cell Carcinoma (SCC) Moderately Differentiated Keratinized. Pada saat ini telah mulai terlihat pembengkakan yang terasa nyeri pada daerah nasolabial kiri. Pasien didiagnosis dengan Karsinoma Sel Skuamosa Palatum Durum (Moderately Differentiated Keratinized). Dilakukan pemeriksaan CT Scan rongga mulut, laboratorium darah lengkap dan rontgen thoraks untuk menentukan stadium tumor.

Hasil CT-scan rongga mulut memperlihatkan lesi isodens inhomogen di daerah palatum terutama sinistra, batas tidak tegas, tepi ireguler, tampak destruksi pada os maksila sehingga lesi meluas ke anterior dan kavum nasi sinistra. Didapatkan kesan: tumor palatum dengan destruksi os maksila dan perluasan ke kavum nasi sinistra (gambar 3).

Hasil pemeriksaan darah lengkap dalam batas normal yaitu $\mathrm{Hb} 14,8 \mathrm{~g} / \mathrm{dL}$, leukosit $8.600 / \mathrm{mm}^{3}$, hematokrit 44\%, trombosit $276.000 / \mathrm{mm}^{3}$, PT: 13 detik, APTT: 34 detik. Rontgen thoraks dalam batas normal. Berdasarkan itu ditegakkan diagnosis pasien Karsinoma Sel Skuamosa Palatum Durum (Moderately Differentiated Keratinized) stadium IVa $\left(\mathrm{T} 4 \mathrm{aN} \mathrm{N}_{0} \mathrm{M}_{0}\right)$, pasien lalu direncanakan untuk dilakukan tindakan operasi Maksilektomi Inferior dalam anestesi umum, namun pasien saat itu belum bersedia.

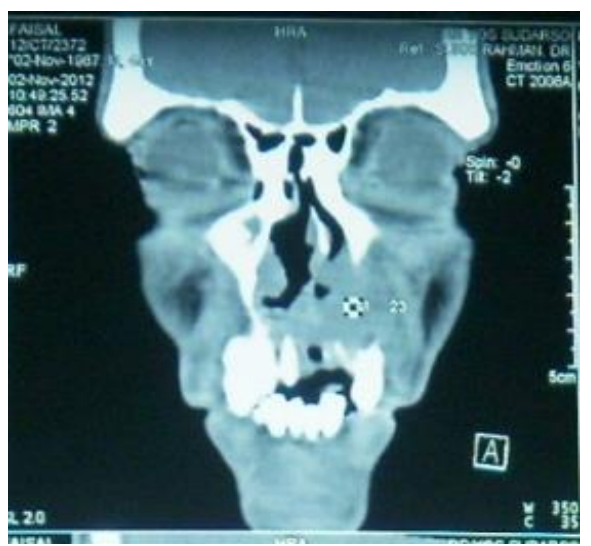

Gambar 3. CT scan rongga mulut potongan koronal, tampak massa telah mendestruksi os maksila bagian anterior dan lantai kavum nasi sinistra

Pada tanggal 19 November 2012 pasien datang kembali ke poliklinik THT-KL dan setuju untuk dilakukan operasi. Untuk persiapan operasi pasien dikonsulkan ke bagian Penyakit Dalam untuk toleransi operasi dan jawaban dari bagian Penyakit Dalam tidak terdapat kontraindikasi untuk dilakukan tindakan dalam anestesi umum. Pasien juga dikonsulkan ke 
bagian Gigi dan Mulut untuk dilakukan persiapan obturator.

Pada tanggal 1 Desember 2012 dilakukan tindakan maksilektomi inferior dalam anestesi umum dengan pendekatan insisi Weber Ferguson.

Dilakukan penandaan insisi pada lateral dorsum nasi sejajar nasomaksila sinistra, lalu dilakukan infiltrasi epinefrin 1:200.000 pada daerah yang akan diinsisi. Operasi dimulai dengan membuat insisi Weber Ferguson pada wajah sisi kiri mulai dari setinggi kantus medial kiri menelusuri dinding lateral dorsum nasi hingga ke ala nasi kiri menembus subkutis dan fasia sampai tampak otot wajah, insisi dibelokkan mengikuti bentuk ala nasi kemudian diteruskan ke dalam dasar hidung, pertengahan kolumela dan filtrum bibir atas. Perdarahan dirawat. Kulit pipi diretraksi ke lateral, tampak massa mendestruksi dinding anteroinferior os maksila dan palatum durum. Dilakukan diseksi secara tumpul dan tajam untuk memisahkan palatum yang telah mengalami destruksi akibat massa tumor dengan jaringan sekitar. Dilakukan reseksi setengah palatum durum (sisi kiri) dengan gigli saw, mulai dari tuberositas maksila kiri sejajar dengan batas palatum mole dengan palatum durum lalu diteruskan ke anterior palatum durum sampai ke prosesus alveolaris antara insisivus 1 dan 2 kanan. Setelah direseksi didapatkan spesimen setengah palatum durum sisi kiri. Sisa pinggir tulang bekas pemotongan yang masih tajam dihaluskan dengan menggunakan bor.

Defek operasi dievaluasi, tampak rongga maksila kiri dan kavum nasi kiri menjadi satu, tidak tampak perdarahan aktif, defek operasi lalu dipasang tampon yang diolesi antibiotik dengan bagian ujung diletakkan pada kavum nasi snistra. Dipasang obturator untuk menutup defek operasi dan menyangga tampon. Untuk intake dipasang NGT melalui kavum nasi dekstra.

Diagnosis pasca operasi adalah pasca maksilektomi inferior atas indikasi Karsinoma Sel Skuamosa Palatum Durum (Moderately Differentiated Keratinized) stadium IVa $\left(\mathrm{T}_{4 a} \mathrm{~N}_{0} \mathrm{M}_{0}\right)$.

Pasca operasi pasien dirawat dan diberikan terapi seftriakson injeksi $2 \times 1 \mathrm{~g}$, drip tramadol 1 ampul dalam 1 kolf $R L 8$ jam/kolf.

Tampon dibuka pada hari ke-3 setelah operasi. Hasil evaluasi tampak krusta kecoklatan menutupi sebagian besar defek operasi dengan beberapa bagian masih terlihat sekret kental kekuningan. Tidak tampak perdarahan aktif.

Pasien pulang pada hari ke-5, diberikan terapi oral siprofloksasin $2 \times 500 \mathrm{mg}$, asam mefenamat $3 \times 500$ $\mathrm{mg}$, ranitidin $2 \times 150 \mathrm{mg}$.

Pasien kontrol kembali ke poliklinik THT-KL 3 hari kemudian, tidak ada keluhan pada luka bekas operasi, pasien mengeluhkan produksi air liur yang berlebihan akibat rasa tidak nyaman pada bagian belakang obturator yang terasa menekan langit-langit dan juga tidak nyaman saat menelan makanan ataupun minuman karena refluks ke rongga hidung. Pada defek operasi masih terlihat krusta kecoklatan dan sedikit sekret mukoid (Gambar 4). Dilakukan aff hecting semua jahitan. Terapi antibiotik dilanjutkan. Pasien lalu dikonsulkan ke bagian gigi dan mulut untuk penyesuaian obturator.

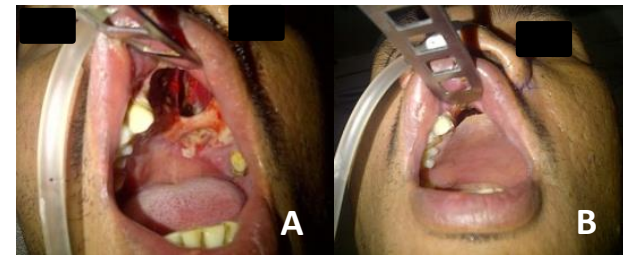

Gambar 4. A. Defek bekas operasi terdapat krusta kecoklatan. B. Saat obturator terpasang

Pada saat kontrol ulang yang ke-2 (dua minggu pasca operasi), masih terdapat keluhan tidak nyaman saat menelan karena makanan dan minuman terasa masuk ke rongga hidung, untuk itu NGT masih dipertahankan. Pasien dikonsulkan kembali ke bagian gigi dan mulut untuk pembuatan obturator yang lebih sesuai.

Luka bekas operasi tampak baik (Gambar 5). Tidak tampak massa tumor. Hasil pemeriksaan histopatologi pasca operasi adalah: Squamous Cell Carcinoma Well to Moderately Differentiated Keratinized (Gambar 6).

Untuk tatalaksana selanjutnya pasien dianjurkan menjalani radioterapi. Karena saat itu sarana radioterapi di RS. Dr. M. Djamil Padang masih belum dapat dipergunakan pasien dianjurkan untuk menjalani radioterapi di RSCM Jakarta, namun pasien menolak karena alasan finansial.

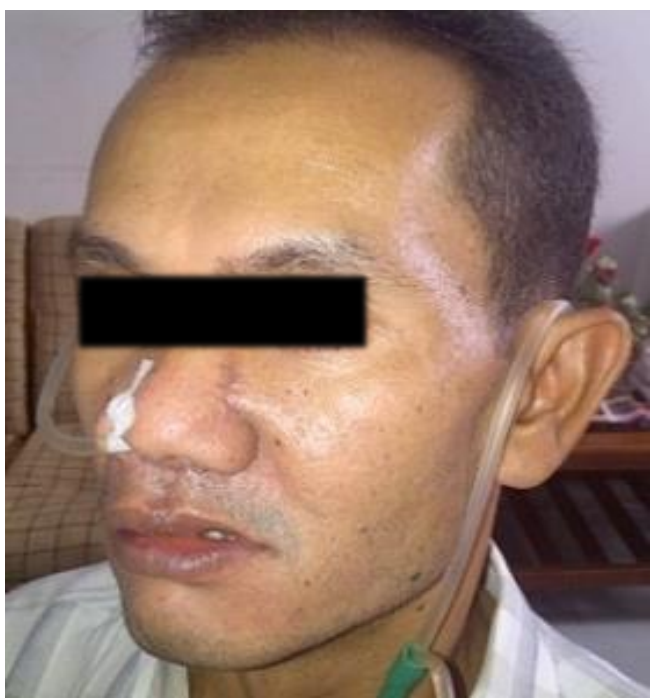

Gambar 5. Luka bekas operasi tampak baik 


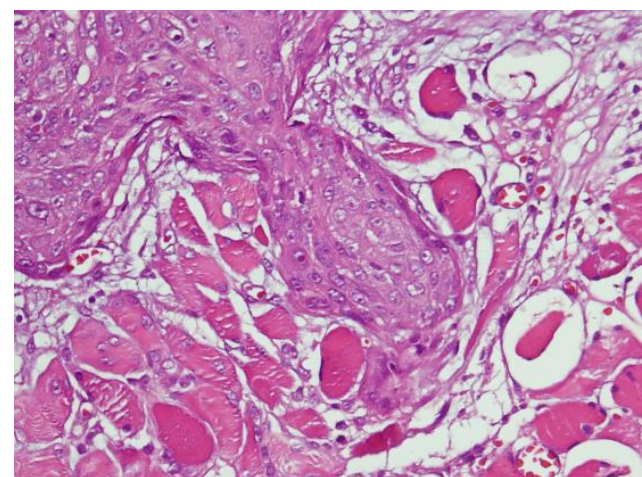

Gambar 6. Gambaran histopatologi, tampak infiltrasi pulau-pulau epitel berlapis gepeng ke stroma dan otot lurik.

\section{DISKUSI}

Telah dilaporkan kasus seorang pasien lakilaki 45 tahun dengan diagnosis Karsinoma Sel Skuamosa Palatum Durum (Moderately Differentiated Keratinized) stadium IVa $\left(\mathrm{T}_{4 a} \mathrm{~N}_{0} \mathrm{M}_{0}\right)$ dengan tindakan maksilektomi inferior.

Li et al, 2011 menyatakan bahwa penelitian jangka panjang di universitas Sun Yat Sen, didapatkan perbandingan kejadian karsinoma sel skuamosa palatum durum antara penderita pria dan wanita yaitu 1:1,02. Gejala klinis terbanyak yaitu pembengkakan tanpa diikuti oleh tanda-tanda infeksi. $^{3}$

Etiologi karsinoma sel skuamosa palatum durum berhubungan erat dengan gaya hidup merokok dan alkohol, diet rendah antioksidan dan virus HPV $16 .^{5,6,7}$ Rehberg, 2009 menyatakan bahwa pengaruh rokok pada rongga mulut dan saluran pernafasan disebabkan oleh panas, iritasi bahan kimia yang terdapat dalam rokok dan toksisitas bahan kimia rokok tersebut. ${ }^{7}$ Ketiga penyebab tersebut akan merusak sel epitel, denaturasi protein, melepaskan histamine dan xantin oksidase. Enzim xantin oksidase akan melepaskan ikatan purin ke asam urat yang melepaskan radikal bebas reactive oxygen species (ROS). Histamine akan merangsang pelepasan Nitric Oxide (NO) yang akan berikatan dengan Reactive Nitrogen Species (RNS) ${ }^{6}$ ROS dan RNS akan merusak permeabilitas membrane, mitokondria dan akan merusak DNA. Pengrusakan DNA oleh RNS dan ROS melalui mekanisme pengikatan RNS dan ROS dengan protein, lipid dan DNA yang megakibatkan inaktivasi enzim untuk sintesa protein sehingga proses replikasi DNA dan pembacaan protein terganggu. Akibat lanjut terjadi mutasi gen yang mengakibatkan munculnya keganasan.,8 Perubahan histopatologis yang terlihat akibat kerusakan sel oleh RNS dan ROS yaitu berupa edema, apoptosis dan keganasan sel. ${ }^{7,8,9}$

Pada pasien ini terdapat riwayat merokok sejak \pm 25 tahun yang lalu, besar kemungkinan hal ini yang berhubungan dengan timbulnya karsinoma palatum durum.

Penggunaan alkohol juga akan meningkatkan resiko keganasan oleh karena ikatan nikotin dan etanol meningkatkan kadar sitotoksin Nnitrosamin yang merusak permeabilitas membran sel. $^{5,10}$

Gejala klinis karsinoma palatum durum seringkali asimptomatis. Massa yang awalnya tidak nyeri merupakan keluhan utama. ${ }^{5,9}$ Massa terkadang disertai oleh ulserasi yang pada awalnya tidak terasa sakit akan tetapi pada perkembangan penyakitnya kemudian dapat memberikan sensasi nyeri. ${ }^{9}$ Gejala klinis lainnya yaitu perdarahan dari massa, bau mulut, nyeri dan goyah pada gigi, susah menelan dan trismus. ${ }^{5,9}$

Pemeriksaan telinga diperlukan untuk mengetahui invasi tumor kearah tuba eustachius dan otot tensor veli palatini. Pemeriksaan lainnya yaitu hiperestesia palatum, yang mengindikasikan penyebaran pada nervus trigeminus cabang maksilaris pada fossa sfenopalatina. ${ }^{5}$

Pemeriksaan penunjang yang diperlukan yaitu CT-Scan, diperlukan untuk melihat massa tumor, luasnya invasi dan kerusakan tulang yang telah terjadi. Potongan koronal diperlukan untuk mengevaluasi perluasan tumor ke superior dan sinus paranasal. $^{5}$

Terapi untuk keganasan ini dapat berupa pembedahan, radiasi dan kombinasi. Pembedahan yang dapat dilakukan pada tumor palatum yaitu alveolektomi, reseksi palatektomi, maksilektomi inferior. $^{2,10}$

Maksilektomi inferior dilakukan pada tumor yang terbatas pada palatum, lantai sinus maksila dan kavum nasi. Dilakukan reseksi pada palatum durum dengan dapat melibatkan dinding sinus maksila, lantai kavum nasi dan konka inferior namun tidak memotong lantai orbita dan sinus etmoid. ${ }^{6}$ Pada pasien ini dipilih tindakan maksilektomi inferior karena tumor berasal dari palatum durum dengan perluasan terbatas pada dinding anterior maksila dan lantai kavum nasi sinistra.

Ukuran tumor yang lebih besar memerlukan insisi Weber Ferguson yang dimodifikasi. ${ }^{10}$ Pada pasien ini dipilih pendekatan dengan insisi Weber Ferguson karena selain tumor yang sudah meluas hingga ke dinding anteroinferior maksila juga karena operator lebih terbiasa dengan teknik ini.

Insisi Weber Ferguson yang dilakukan pada pasien ini mengikuti bentuk lengkungan ala nasi sehingga secara kosmetik memberikan hasil yang lebih baik, ini terlihat pada saat pasien kontrol ulang 2 minggu setelah operasi, luka operasi sudah tersamarkan.

Penggunaan obturator sementara segera setelah operasi penting untuk membantu pemberian nutrisi peroral sehingga mempercepat rehabilitasi pasien. ${ }^{2}$ Keluhan tidak nyaman pasien ini pada saat menelan makanan dan minuman akibat refluks ke hidung kemungkinan akibat bentuk dan ukuran obturator yang kurang sesuai. Hal ini bisa terjadi karena pengukuran obturator dilakukan sebelum operasi hanya berdasarkan perkiraan luas daerah 
yang akan dioperasi. Sedangkan temuan saat operasi bisa saja berbeda, untuk itu penting dilakukan pembuatan kembali obturator yang lebih sesuai bentuk dan ukurannya setelah operasi.

Prognosis karsinoma sel skuamosa palatum durum ini cukup baik, yang dinyatakan oleh penelitian Truitt, 1999 yaitu pada kasus yang telah dilakukan operasi diikuti dengan pemberian radioterapi, angka harapan hidup lima tahun adalah sebesar $76 \%$, Hal ini karena bagian dari tulang maksila inferior yang dikenai tumor tidak sulit untuk direseksi dan karakteristik tumor yang respon terhadap pemberian radioterapi. ${ }^{2}$ Namun pada kasus ini pasien setelah dioperasi menolak anjuran untuk menjalani radioterapi karena alasan finansial, hal ini dapat memperburuk prognosis.

\section{DAFTAR PUSTAKA}

1. Chen, $\mathrm{P}$, Lin, F, Helen, HW, Chen, Hsiao JR, Yang, MW, Hsueh WT, Tasi, ST, Lin, FC, Wu, YH. Intensity-Modulated Radiotherapy Improves Outcomes in Postoperative Patients With Squamous Cell Carcinoma of The Oral Cavity. Oral Oncology. 48 ${ }^{\text {th }}$ Edition. Taiwan: National Cheng Kung University. 2012. p 747-52.

2. Truitt, TQ, Gleigh, LL, Huntress, GP, Gluckman, JL. Surgical Management of Hard Palate Malignancies. Otolaryngology-Head and Neck Surgery. $121^{\text {st }}$ edition. Ohio: Taylor's University. 1999. P 548-62.

3. Li, Q, Zhang, XR, Liu, XK, Liu, ZM, Liu, WW, Li, Hao, Guo, ZM. Long-term Treatment Outcome of Minor Salivary Gland Carcinoma of The Hard Palate. Oral Oncology. $48^{\text {th }}$ Edition. Taiwan: National Cheng Kung University. 2012. p 456-62.
4. Sadeghi, N. Malignant Tumours of The Palate. Available at http://www. http://emedicine.medscape.com/article/847807overview\#showall. Accessed at 8 March 2013.

5. Rodman, R, Watts, TL. Tomuors of The Hard Palate and Upper Alveolar Ridge. Grand Rounds Presentation, The University of Texas Medical Branch Departement of Otolaryngology. Texas, 22 April 2011.

6. Fagan, J. Atlas of Otolaryngology, Head and Neck Operative Surgery. Available at http://www.entdev.uct.ac.za. Accesed at 20 Februari 2013.

7. Rehberg, S, Maybauer, MO, Enkhbaatar, P, Maybauer, DM, Yamamoto, Y, Trabel, D. Pathophysiology, Management and Treatment Smoke Inhalation Injury. Expert Review of Respiratory Medicine. $3^{\text {rd }}$ edition. London: $\mathrm{NIH}$ Public access. 2009. p 283-87.

8. Lombard, DB, Chua, KF, Mostoslavsky, R, Franco, S, Gostissa, M, Alt, FW. DNA Repair, Stability and Aging. Cell. $120^{\text {th }}$ edition. Boston: Elsevier. 2010. p 497-512.

9. Rad, M, Kakoie, S, Brojeni, FN, Pourdamgahn, N. Effect of Long-term Smoking on Whole Mouth Salivary Flow Rate and Oral Health. Journal of Dental Research, Dental Clinic, Dental Prospect. $4^{\text {th }}$ edition. Iran: Tabriz University. 2010. p 110-14.

10. Shah, J, Patel, S, Singh, B. Resection of Maxila for Tumors Upper of the Alveolous and Hard Palate. Head and Neck Surgery and Oncology. $4^{\text {th }}$ edition. New York: Elsevier. 2012. p 670-85.

11. Head and Neck Cancer Centre. Palate Cancer. Available at: http://www.headandneckcentre.com. Accessed at 23 Februari 2013. 